\title{
The Employment and Income Performance of Immigrants in Sweden, 1970-19901
}

\section{PIETER BEVELANDER}

\section{Lecturer}

\section{KIRK SCOTT}

\section{Lecturer}

Department of Economic History

Lund University

Lund, Sweden

\begin{abstract}
In recent decades, Sweden has suffered from a relatively low growth rate, while undergoing a transformation towards increased service sector employment and decreased industrial employment. Simultaneously with the economic changes, the constitution of immigration to Sweden has also changed significantly, shifting from European labor migrants to non-European refugees and tied movers. This paper discusses the forces behind the decreasing labor market attachment among immigrants to Sweden in the period 1970-1990. Points of special interest here are employment rates and relative incomes of various immigrant nationalities. This is accomplished through the charting of labor force participation rates and employment patterns of different immigrant groups over the period in question. The statistics in this paper are based on the five most recent Swedish censuses, from which we have data at the individual level regarding age, sex, country of origin, employment status, sector of employment, and immigration year.
\end{abstract}

Keywords: employment rate, income, immigrants, Sweden

\section{Introduction}

The Swedish society developed during the first two decades of the postwar period into one of the wealthiest countries in the world. This change in the wealth of the country was accompanied by immigration on a previously unknown scale. Sweden's remarkable economic growth has been facilitated by this immigrant flow, which consisted almost entirely of European labor migrants during the period up to the early-

\footnotetext{
This paper is part of a larger research project entitled
}

"Migrants in the Post-Industrial Age: Immigration and Structural Change in the Swedish Economy, 1968-1993," supported by the Swedish Council for Social Research. The project is being carried out by members of the Research Group in Population Economics, Department of Economic History, Lund University. 
1970s. Over the past twenty years this symbiotic relationship has changed drastically, however. The Swedish economy has suffered from a relatively low growth rate, while undergoing a transformation towards increased service sector employment and decreased industrial employment. Simultaneously with the economic changes, the constitution of immigration to Sweden has also changed significantly, shifting from European labor migrants to non-European refugees and tied movers. ${ }^{2}$

We thus have experienced a changing immigrant labor market from both a demand as well as a supply perspective. It is this combination of factors which is believed to lie behind the decreasing labor market attachment of migrants, specifically the lower employment rates and lower relative incomes that have been noticeable over the past decades.

This paper will discuss the forces behind this decreasing labor market attachment among immigrants to Sweden in the period 1970-1990. Points of special interest here are labor force participation rates and relative incomes of various immigrant nationalities.

The strengths of this paper lie in the fact that data on the entire immigrant population at the individual level is utilized, avoiding problems associated with panel data. The paper also combines a structural-analytical approach with human capital theory in an attempt to account for both demand and supply forces on the immigrant labor market. Earlier research has concentrated upon human capital composition of migrants, with only minor mention given to economic structure. We propose here a new view to the problem which also incorporates structural change in the economy as an important factor in the economic assimilation process of immigrants.

\section{Earlier research}

Earlier research regarding the economic integration of immigrants into the Swedish society has pointed to the very high labor market attachment during the $1950 \mathrm{~s}$ and 1960 s. These studies refer to high employment rates, low unemployment and relatively high incomes among both male and female citizens of foreign countries (Wadensjö 1973; Ohlsson 1975; Ekberg 1983). Current research into the situation of the 1970s and 1980 s shows a different picture evolving, characterized by extremely low immigrant participation rates. Not even the cyclical upswing of the late 1980 s served to raise the employment rates or incomes of immigrants. In fact, the opposite actually occurred, with decreasing rates throughout the decade for recent migrants and, remarkably, also for migrants who had resided in Sweden over an extended time period (Ekberg 1991a and 1991b).

This trend has also been noted in international immigration research. Studies of immigrant cohorts to the USA during the 1960s show a positive relationship between labor market assimilation, primarily in the form of income, and increasing time in the country (Chiswick 1978). Later investigations used data in which income was recorded at more than one point in time (Borjas 1985, 1987, and 1989). The main findings of this work was that the assimilation of immigrants to the USA depends on country of origin and time of immigration. Research of cohorts entering the United States and Canada during the 1980 s tells a different tale, being much less positive concerning the income catch-up process of immigrants (see e.g. LaLonde and Topel 1992; Wright

2 Tied movers refer here to those immigrants entering Sweden for non-economic, non-refugee reasons. This generally means relatives of earlier migrants or those with connections to Swedish citizens. 
and Maxim 1993). Despite the poorer income alignment, the assimilation process during this period is argued to have remained stable (LaLonde and Topel 1992).

The hypothesis concerning the development of the Swedish economy as one of the major factors causing the deterioration of the labor force attachment of the immigrant population, is based on a number of assumptions. The approach here described is based on a long term cyclical development and formulated as a generalization of the Swedish experience in the international environment (Schön 1990, 1991, 1993 and 1994). Further, this model is characterized by a cycle of approximately 40 years and consists of three main phases: transformation, rationalization, and crisis. The transformation phase is distinguished by new directions of production, high long-term investment, diffusion of important innovations as well as liberal credit, and state debt policies and increasing importance of the home market. The more export-oriented rationalization phase is characterized by increasing competition, nationally and internationally, and lower profit margins for companies leading to shifts in investments towards rationalization, increasing efficiency within established lines of production. Companies' lower expectations and falling willingness to invest, coupled with changing consumer demand patterns leads to the structural crisis which gives way to creative destruction and the possibility to start new businesses and enter a new period of longterm economic development.

An important component in this model is that employment-demand patterns follow the different characteristics needed in the labor market during the transformation and rationalization phases. The content as well as the size of the employment fluctuate between these phases. During the transformation phase investments are expansive and capacity increases, which increases employment. But at the same time the transformation phase is characterized by the introduction of new methods and products, where new skills gain in importance leading to an increase in employment of higherskilled workers.

Basically, it is assumed in this paper that the structural change of the economy with a relatively decreasing industrial and increasing service sector during the last decades implied a long-term change to more information- and communication-intense working processes. The development during the late 1970 s and 1980 s involved increasing demand for employees with a proportionately higher general competence, while unskilled labor was made redundant by efficiency improvements. Serial production, automation, and specialization were increasingly replaced by teamwork, influence on working processes and varying assignments. Without reducing the importance of formal education and skill, the importance of informal competence increased. This informal competence includes, for instance, culture-specific proficiency, language skills and the understanding of different patterns of behavior in teamwork and in relations with authorities and labor market organizations.

\section{History}

A simplified view of immigration to Sweden would divide the post-war period into two eras, with the first being characterized by primarily labor-force immigration, while the second saw a shift towards refugee and tied immigration. This first period can be said to have existed from 1945 up to the years around 1970. During this time, Sweden's economy expanded rapidly, in part due to the destruction experienced by her European neighbors. This rapid expansion could not be met by an appropriate increase in the Swedish labor force, and the introduction of foreign workers was necessary in order to avoid bottlenecks in production. The problem was solved in the 1950 s through the import of skilled labor, which served as a complement to the native labor force. 
This skilled labor was mainly recruited in northwestern Europe with the majority coming from Western Germany, Italy, and the Nordic countries (See Table 1).

The 1960 s, on the other hand, saw the beginnings of a rationalization period, and the type of labor demanded from immigrants shifted towards primarily unskilled or low-skilled workers. These workers, in contrast to their counterparts of a decade earlier, were used more as substitutes for the native workforce than as complements. While earlier immigrants allowed the economy to grow in size, the immigrants of the 1960s facilitated a widening of the economy. As these immigrants arrived in Sweden, they found employment in jobs vacated by Swedes during the expansion of the service sector. The fact that these newly vacated jobs could be filled by unskilled workers is a result of industrial investment aimed at increasing international competitiveness and reducing costs (Lundh and Ohlsson 1994; Ohlsson 1975, 1978). Labor-force immigrants during this decade came largely from Nordic countries but also from Mediterranean countries like Greece, Yugoslavia and Turkey (See Table 1).

By the end of the 1960 s, however, the situation began to change for the immigrants. The trade unions saw immigration as producing a number of negative side effects. One such side effect was the delaying of industrial transformation through the steady supply of workers to replace Swedes who moved into the service sector. This supply of labor also served to depress wage increases in industry, which could otherwise have occurred due to scarcity of labor. In this way, immigration was seen as preserving the traditional industrial structure in a time when it would otherwise have been forced to undergo large changes. The government responded to this criticism through a change in the rules governing entrance to Sweden. The new rules entered force in 1968 , and meant that future applicants for work and residence permits from non-Nordic countries must apply before they enter the country, and at that time have arranged for both a job and a place to live. This dramatically cut down the labor immigration of non-Nordic countries during the next decades.

As stated earlier, Swedish economic growth dropped to a lower level following the crisis of the early 1970s. At the same time the economy passed through a period of transformation with a decreasing industrial sector and an increasing service sector. The common base of jobs in the service sector are culture specific knowledge or social competence, in which language, communication ability and familiarity with the functioning of the Swedish society is crucial. Nordic labor migration, especially Finnish, gradually declined largely because of a diminishing gap in the standard of living between Sweden and Finland and an increasing demand for labor in Finland. While labor migration dwindled, other types of migration, mainly tied movers and different categories of refugees, increased substantially during the 1970 s and 1980 s. This also led to a major shift in the country of origin mix of the immigrant population, with a greater share of non-European immigrants having non-economic motives behind their migration. The major contributors to the immigrant population in Sweden during this period were Iranians, Turks, and others from Middle Eastern countries (See Table 1)

\section{Data and method}

A problem with the Swedish and international research to date is that it has often been at a highly aggregated level, with immigrant groups consisting of various nationalities and cultural characteristics. This complicates identification of differences between the various nationalities. Another large problem is that these studies are often based upon samples which involve a certain reduction in reliability based on sample selection methods and biases. 
T a b l e 1. Foreign-born population in Sweden for selected countries.

$\begin{array}{lrrrrr}\text { Country / Year } & 1970 & 1975 & 1980 & 1985 & 1990 \\ \text { Swedish-born } & 7,539,318 & 7,658,093 & 7,690,282 & 7,702,491 & 7,800,185 \\ \text { Foreign-born } & 537,585 & 550,451 & 626,953 & 655,649 & 790,445 \\ \text { Nordic-born } & 320,913 & 315,775 & 341,253 & 315,184 & 319,082 \\ \text { European-born } & 176,463 & 181,488 & 190,990 & 200,215 & 220,806 \\ \text { African-born } & 4,149 & 5,849 & 10,025 & 13,919 & 27,343 \\ \text { North American-born } & 15,629 & 14,575 & 14,484 & 15,660 & 19,087 \\ \text { South American-born } & 2,300 & 5,290 & 17,206 & 26,247 & 44,230 \\ \text { Asian-born } & 9,841 & 19,605 & 45,112 & 76,529 & 150,487 \\ \text { Danish-born } & 39,152 & 48,302 & 43,501 & 41,159 & 43,931 \\ \text { Finnish-born } & 235,453 & 222,147 & 251,342 & 228,050 & 220,497 \\ \text { Norwegian-born } & 44,681 & 43,842 & 42,863 & 42,856 & 52,744 \\ \text { West German-born } & 41,793 & 39,543 & 38,696 & 37,458 & 36,558 \\ \text { Greek-born } & 11,835 & 14,676 & 15,153 & 13,632 & 13,171 \\ \text { Yugoslavian-born } & 33,779 & 36,956 & 37,982 & 38,380 & 43,346 \\ \text { Italian-born } & 7,268 & 6,222 & 6,062 & 5,868 & 5,989 \\ \text { Polish-born } & 10,851 & 14,461 & 19,967 & 28,658 & 35,631 \\ \text { Czechoslovakian-born } & 7,392 & 7,228 & 7,529 & 7,830 & 8,432 \\ \text { Ethiopian-born } & 346 & 902 & 1,797 & 3,204 & 10,027 \\ \text { Turkish-born } & 3,768 & 6,143 & 14,357 & 19,264 & 25,528 \\ \text { Iranian-born } & 411 & 998 & 3,348 & 8,900 & 40,084 \\ \text { Lebanese-born } & 240 & 486 & 2,170 & 4,709 & 15,986\end{array}$

Source: Statistics Sweden Population Statistics

This paper charts employment rates and income levels of different immigrant groups over the period in question (Bevelander 1995; Scott 1995). The statistics are based on the five most recent Swedish censuses $(1970,75,80,85,90)$, from which data can be obtained at the individual level regarding age, sex, education, civil status, country of origin, employment status, sector of employment, and year of immigration.

The definition of immigrants is the same as the one for first-generation immigrants, or foreign born as it was registered during the censuses of 1970-1990. Children born in Sweden to immigrant parents are not included in the study. The statistical material examined consists of the total population of working age 16-65, taken from the Swedish censuses which are carried out every five years. The lower age limitation, 16 years of age, is explained by the fact that school attendance is compulsory until the age of 16 , while the upper age limitation, 65 years of age, is legal retirement age in Sweden. Since these are cross-sectional data, the construction of a yearly series is impossible at present, but work on such a database is currently underway in Lund.

\section{Employment rate}

The basic definition of employment rate in this investigation is the quotient between those who have employment and the registered population. The censuses of 1970 , $1975,1980,1985$, and 1990 have different degrees of margin of error regarding employment data. The omissions for the censuses of 1970, 1975 and 1980 are minimized by only calculating the labor force participation rates of those persons with certain information. ${ }^{3}$ Persons with "no employment information" are deleted from in the numer-

${ }^{3}$ One reason for omissions is individuals not responding to the census, and this can be corrected by eliminating those with no employment information from the population. 
ator and denominator when calculating the employment rates. The omissions in the 1985 and 1990 censuses are minimized by calculating the labor force participation rates of those persons who actually answered the census. ${ }^{4}$ In this way a group with "no employment information" is eliminated. The same calculation procedure as in the earlier three censuses is used and gives the upper limit of the immigrants' labor force participation and the possibility to compare the different censuses over time. To be registered as employed a person has to be employed one hour or more per week during the month of census data collection.

Table 2 shows the development of the employment rate of different immigrant groups between 1970 and 1990. In general, it shows that foreign-born men have a decline of more than 15 percentage points in employment rate during this period. Immigrants born in the Nordic countries, Western Europe, Eastern Europe, Latin and North America as well as in South Asia are somewhat above this level in the 1990 census, while men born in Southern Europe, Africa, East Asia, and the Middle East are beneath this level. Characteristic for most of the groups is the gradually decreasing employment rate after the 1970 census, especially for the large labor migration groups which came during the 1950 s and 1960 s. Other groups show this decrease first after the 1975 census. Also, many groups show an increase between the censuses of 1985 and 1990 which could be caused by the very favorable Swedish labor market during the end of the 1980 s.

The main feature of the female employment rate during this period is the increase in participation of nearly all groups. Foreign women as a whole increased their employment rate by 10 percentage points between 1970 and 1990. Labor migration groups (Nordic, West, South and East European, and North American) immigrating during the 1950s and 1960s show the largest increase, except for the South European women. Of the immigrant groups arriving during the 1970s and 1980s, Latin Americans, and East- and South Asians show increasing rates during the period. Middle Eastern women show a decline in participation after 1975. African women, who came in larger numbers during the late $1980 \mathrm{~s}$, show a heavy decline in employment between the censuses of 1985 and 1990.

Compared to Swedish women, who show an exceptional increase in labor force participation during this period, female immigrant groups show a slower increase in their employment rate (or no increase at all).

The problem with the participation rates of the different groups in the different censuses shown in Table 2 is that they account for the stock of every immigrant group in the respective census year, irrespective of when immigrants came into the country.

In line with earlier investigations of the income catch-up process and time spent in the new country, the employment rate by immigrant year cohort for different groups based on the censuses of 1970 and 1990 is presented below.

Figure 1 presents immigrant groups who immigrated during the postwar period up to the 1970 census, mainly labor immigrants. Figures 2 and 3 present immigrant groups with the larger part immigrating during the 1970 s and 1980 s, primarily refugees and tied movers. In the figures we go back in time by five-year periods and present rates for every cohort. In this way a proxy for the adaptation time of different immigrant groups in Sweden is shown during different periods. Care must be taken however, since the diagrams do not represent one single cohort over time.

Earlier research based on human capital and examining the incomes of immigrants argues for a rapid income catch-up process of immigrants arriving prior to 1970. The

${ }^{4}$ In 1985 and 1990 employment information did not come directly from the census questionnaire, so the variable "cohabitation" was used to indicate actual response to the census. 
employment rates of immigrants arriving during this period equals the rates of natives and for some groups even exceed Swedish levels. A look at Figure 1 shows that cohorts of different male and female immigrant groups show high rates in the census of 1970 compared to Swedish born males and females who in this census have employ-

T a b l e 2. Age-standardized employment rate of Sweden and selected immigrant groups, $1970-1990$

\begin{tabular}{|c|c|c|c|c|c|c|c|c|c|c|}
\hline \multirow[b]{2}{*}{ Year } & \multicolumn{5}{|c|}{ Male } & \multicolumn{5}{|c|}{ Female } \\
\hline & 1970 & 1975 & 1980 & 1985 & 1990 & 1970 & 1975 & 1980 & 1985 & 1990 \\
\hline vedish-born & 84.3 & 83.9 & 82.8 & 82.7 & 83.5 & 52.1 & 62.4 & 69.2 & 76.2 & 80.1 \\
\hline born & 86.8 & 81.8 & 76.8 & 72.7 & & & 63 & 65.3 & 67.7 & \\
\hline ordic-born & 87.8 & 82.2 & 78.1 & 75.9 & 76.4 & 56.3 & 63 & 67.2 & 72.4 & \\
\hline Vest European-born & 86.6 & 85.5 & 81.7 & 77.9 & 79.2 & 2.7 & 60.7 & 65.5 & 68.9 & \\
\hline outh European-born & 86.4 & 79.3 & 73 & 69 & & 8.3 & 66.7 & 63.3 & 61.1 & \\
\hline ist European-born & 80.4 & 79.9 & 75.7 & 72.1 & 72. & 5.0 & 61.3 & 61.9 & 63.8 & \\
\hline rican-born & 73.5 & 74 & 70.6 & 68.1 & 63. & 8.8 & 50.1 & 53.8 & 57.5 & \\
\hline ican-born & 3.4 & 75 & 76.6 & 71.6 & & 6 & 54.6 & 3.6 & 65.4 & \\
\hline -born & 73.6 & 64.5 & 64.4 & 68.1 & 74. & 46.6 & 46.8 & 50.1 & 59.1 & \\
\hline ast & 73.7 & 80.3 & 74.7 & 67 & 68 & 44.1 & 54.5 & 52.4 & 53.2 & \\
\hline $\mathrm{m}$ & 74.9 & 76.6 & 75.9 & 70.5 & 72 & 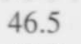 & 53.7 & 51.2 & 52.6 & \\
\hline gorn & 77.1 & 72.9 & 62.7 & 53.9 & 50 & 2 & 49.4 & 38 & 38.5 & 4.1 \\
\hline orn & 87.8 & 86.8 & 82.8 & 78.7 & & & 58.4 & 65.7 & 69.8 & 74.5 \\
\hline rn & 87.6 & 80 & 75.6 & 74.8 & & & 64.3 & 6 & 3.1 & \\
\hline or & 84.7 & 82.9 & 79 & 72.3 & & & 58 & .7 & 8.1 & \\
\hline West German- & 87.7 & 86.6 & 82.4 & 78.4 & & & 61.6 & - & 71.3 & \\
\hline eek-born & 84.1 & 77.1 & 67 & 63.2 & 62 & 53 & 66.8 & 61.1 & 54.4 & 8. \\
\hline avian-born & 86.6 & 79.2 & 72.7 & 68.2 & 66.8 & 58.5 & 67.1 & 62.6 & 61.4 & 57.9 \\
\hline 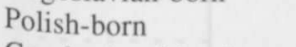 & 73.5 & 78 & 74.1 & 67.5 & 69. & 47.8 & 57.8 & 58.7 & 59.9 & $63.7-7 \cdot x-2$ \\
\hline kian-bo & 83.6 & 72 & 75 & 74.3 & & & 58.7 & & 66.6 & \\
\hline born & NA & NA & 56.4 & 69.2 & 70 & & & 8 & 63.2 & \\
\hline -born & 80.3 & 76 & 66.5 & 61.9 & 54. & 47.9 & 59.2 & 39.2 & 41.6 & 40. \\
\hline -born & NA & 57.5 & 56.4 & 41.8 & 45 . & NA & 33.6 & 37.3 & 42.2 & 30 \\
\hline & & & 67 & 50 & & & NA & 38.5 & 36 & \\
\hline Italian & 86.7 & 81.5 & 79.4 & 73.1 & 71.8 & 59.4 & 60.7 & 61.2 & 61.8 & \\
\hline
\end{tabular}

Source: Statistics Sweden, 1970, 1975, 1980, 1985 and 1990 Censuses of the Population

F i g u r e 1. Employment rate of different immigrant groups by immigration year cohort, 1970 Census. Swedish males $=84.3$, Females $=52.1$

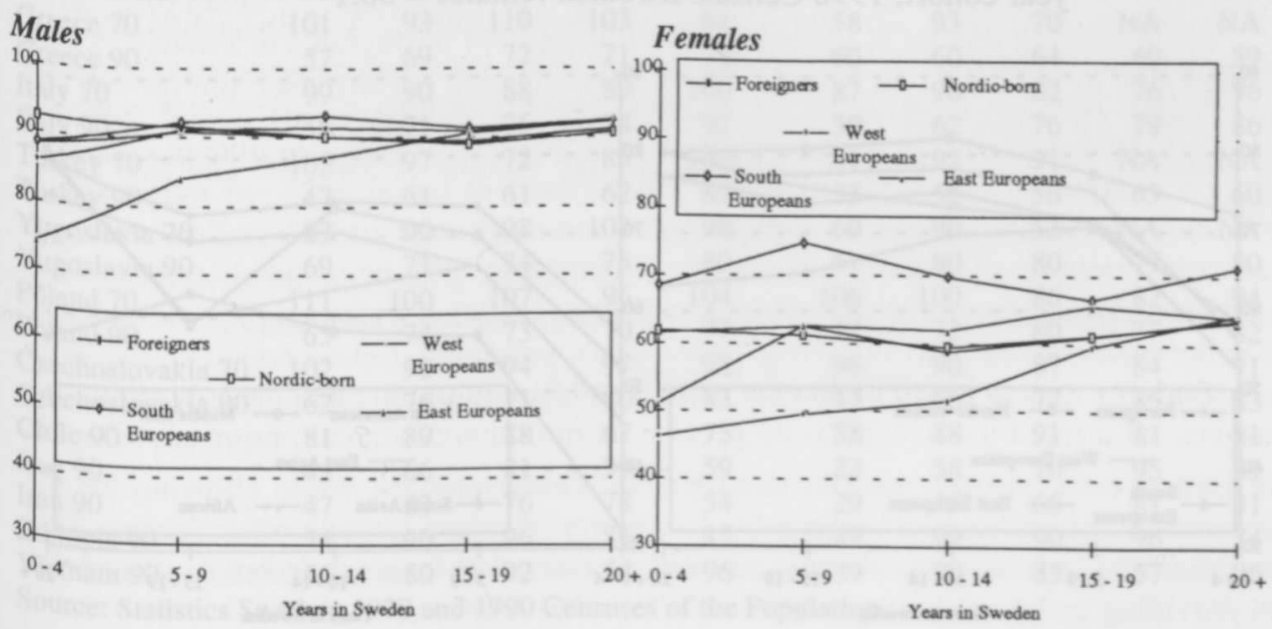


ment rates of $84.3 \%$ and $52.1 \%$ respectively. In particular, the high on-entry labor force participation rates of the male and female immigrant groups could be seen as proxies for fast adaptation to the Swedish labor market of these immigrant groups

Research on cohorts arriving during the period following 1970 show lower rates of employment and income for immigrants. Figures 2 and 3 show the labor force participation rates of immigrant groups arriving during the 1970 s and the 1980 s registered in the census of 1990 . When compared to the employment rate of natives $(83.5 \%$ for men and $80.1 \%$ for women), the figures show lower rates for the cohorts entering Sweden in this period, especially the on-entry labor force participation rates.

Comparing the immigrants coming during the 1950 s and 1960 s to the immigrants coming during the 1970 s and 1980 s, the differences are obvious. More recently immigrated groups show higher on-entry differentials and slower adaptation to native rates of employment. Further, the splitting of the immigrant groups in a group of tied mov-

$\mathrm{F}$ i g u re 2. Employment rate of different male immigrant groups by immigration year cohort, 1990 Census. Swedish males $=83.5$
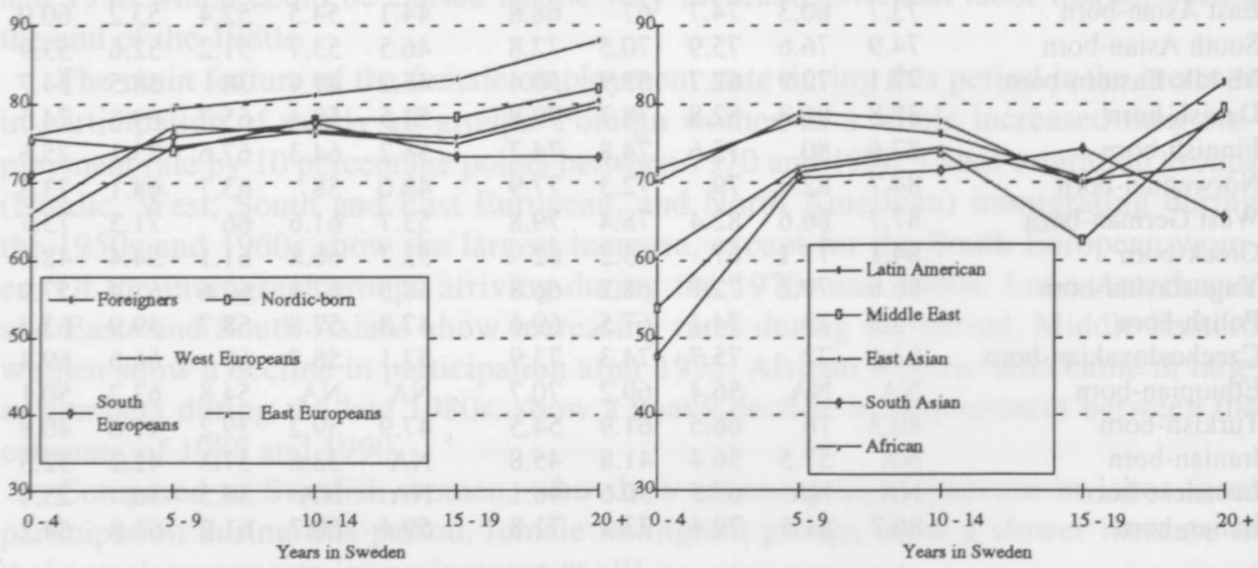

F i g u re 3. Employment rate of different female immigrant groups by immigration year cohort, 1990 Census. Swedish females $=80.1$

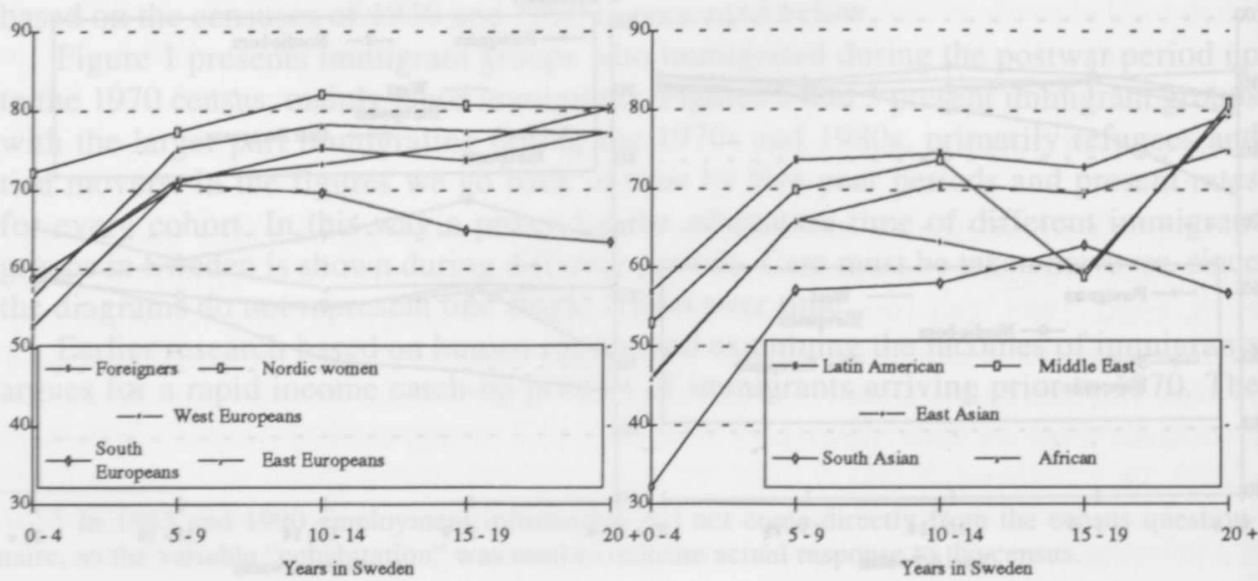


ers (except the Nordic countries) and refugees (Figures 2 and 3 ) is in line with the concept that later immigrant groups can take advantage of countrymen already established in the new country. On the other hand, these figures cannot tell us if this is the main reason for lower employment rates of the refugee immigrant groups. Another reason could be the cultural proximity of these various countries to Sweden. Table 3 shows the probability of immigrants from certain countries having employment relative to Swedes of the same sex, educational level, and civil status. Results similar to those in Figures 2 and 3 were obtained through the use of a simple logistic regression. With this increased specificity, the main result is the large difference between rates obtained by cohorts arriving before 1970 and those coming after 1970. Immigrants who came to Sweden prior to 1970 had fewer problems gaining employment than did their later counterparts. The table also indicates that a lowering of the chance of finding work does seem to occur as cultural distance between the home and destination country increases. This difficulty seems to be fairly short-lived, however, with a closing of the gap between foreigners occurring with increased time in the country, but it nonetheless gives us reason to believe that culture-specific human capital demands in the labor market could complicate a smooth labor market assimilation of immigrants.

Our belief is that not only the supply side, but also the demand side of the labor market had a great deal of impact on the lower employment rate levels of old and new

T a b le 3. Relative probability of having employment for selected nationalities, by time in country, $1970 \& 1990$. Controlling for educational level and civil status. Sweden $=100$.

\begin{tabular}{|c|c|c|c|c|c|c|c|c|c|c|}
\hline & & & Male & & & & & Female & & \\
\hline $\begin{array}{l}\text { Years in } \\
\text { Sweden }\end{array}$ & $\begin{array}{c}1-4 \\
\text { Years }\end{array}$ & $\begin{array}{c}5-9 \\
\text { Years }\end{array}$ & $\begin{array}{l}10-14 \\
\text { Years }\end{array}$ & $\begin{array}{l}15-19 \\
\text { Years }\end{array}$ & $\begin{array}{c}20+ \\
\text { Years }\end{array}$ & $\begin{array}{c}1-4 \\
\text { Years }\end{array}$ & $\begin{array}{c}5-9 \\
\text { Years }\end{array}$ & $\begin{array}{l}10-14 \\
\text { Years }\end{array}$ & $\begin{array}{l}15-19 \\
\text { Years }\end{array}$ & $\begin{array}{r}20 \\
\text { Yea }\end{array}$ \\
\hline Norway 70 & 101 & 88 & 86 & 100 & 103 & 116 & 88 & 110 & 97 & \\
\hline Norway 90 & 83 & 67 & 86 & 90 & 96 & 75 & 68 & 84 & 91 & \\
\hline Denmark 70 & 91 & 90 & 89 & 92 & 100 & 110 & 90 & 97 & 92 & \\
\hline Denmark 90 & 87 & 80 & 84 & 91 & 96 & 71 & 73 & 87 & 92 & \\
\hline inland 70 & 78 & 92 & 96 & 99 & 98 & 90 & 92 & 91 & 86 & \\
\hline Finland 90 & 73 & 78 & 85 & 85 & 94 & 78 & 88 & 96 & 96 & 10 \\
\hline Germany 70 & 100 & 92 & 92 & 96 & 98 & 109 & 92 & 103 & 91 & \\
\hline Germany 90 & 71 & 68 & 88 & 89 & 95 & 49 & 64 & 82 & 86 & \\
\hline United States 70 & 111 & 97 & 90 & 108 & 101 & 120 & 97 & 101 & 114 & \\
\hline United States 90 & 58 & 74 & 79 & 80 & 89 & 42 & 51 & 62 & 74 & \\
\hline Greece 70 & 101 & 93 & 110 & 103 & 94 & 58 & 93 & 70 & NA & \\
\hline Greece 90 & 57 & 69 & 72 & 71 & 74 & 60 & 60 & 64 & 60 & \\
\hline Italy 70 & 99 & 90 & 88 & 89 & 100 & 87 & 90 & 2 & 76 & \\
\hline Italy 90 & 58 & 71 & 75 & 74 & 92 & 39 & 62 & 76 & 79 & \\
\hline Turkey 70 & 105 & 97 & 72 & 89 & 105 & 81 & 97 & 91 & NA & \\
\hline Turke & 47 & 61 & 61 & 6 & 67 & 33 & 52 & 56 & 63 & \\
\hline avia 70 & 87 & 90 & 98 & 102 & 98 & 60 & 90 & 53 & NA & \\
\hline via 90 & 69 & 71 & . & 75 & 80 & 61 & 80 & 80 & 77 & \\
\hline Poland 70 & 111 & 100 & 107 & 96 & 104 & 106 & 100 & 86 & 82 & \\
\hline Poland 90 & 65 & 74 & 73 & 70 & 77 & 47 & 72 & 80 & 77 & \\
\hline Czechoslovakia 70 & 102 & 90 & 94 & 97 & 98 & 96 & 90 & 87 & 84 & \\
\hline oslovakia 90 & 62 & 76 & 7 & 8 & 83 & 43 & 66 & 77 & 85 & \\
\hline Chile 90 & 81 & 89 & 8 & 67 & 73 & 58 & 88 & 91 & 81 & \\
\hline Iraq 90 & 43 & 66 & 81 & 99 & 59 & 22 & 58 & 70 & 95 & \\
\hline $\operatorname{an} 90$ & 47 & 63 & 76 & 78 & 54 & 29 & 48 & 65 & 81 & \\
\hline Ethiopia 90 & 74 & 90 & 96 & 86 & 85 & 49 & 99 & 90 & 96 & \\
\hline Vietnam 90 & 56 & 80 & 92 & 54 & 96 & 39 & 70 & 83 & 57 & \\
\hline
\end{tabular}


immigrants. Generally, the employment rate of the immigrants arriving during the 1970 s and 1980s was lower and adapted more slowly than among immigrants of the $1950 \mathrm{~s}$ and 1960s. From a macro level perspective this can probably be partially explained by the transformation of the economy in the 1970s and 1980s. The sector segregation with relatively more immigrants employed in the industrial sector is one reason for lower employment rates of immigrants, with employment in this sector declining relative to the service sector during the 1970 s and 1980 s. Besides, during this period demand for labor was changing in pace with this new transformation of economic life. Labor demand became, to a great extent, based on labor with specialist knowledge in the new, expansive branches of the economy. The common base of these jobs is culture-specific knowledge or social competence, in which language, communication and familiarity with the functioning of the Swedish society are crucial. In other words, despite educational levels only slightly lower than those of the Swedes, the requirements and competence demanded in the labor market did not match the competence of these new immigrants. Immigrant cohorts who arrived before the change and had skills suitable for this earlier period were equally estranged by this new development.

\section{Income performance of immigrants, 1970 and 1990}

Over the past twenty-odd years a debate has raged over the true income performance of immigrants in the United States. Barry Chiswick made some of the first contributions to this debate, the most renowned being his 1978 article "The Effect of Americanization on the Earnings of Foreign-born Men" (Chiswick 1978). In this article he argues that white male immigrants to the US have an earnings profile that increases over time, eventually equaling native earnings by the thirteenth year in the country, and then surpassing them as time goes by. The data used for this article came solely from the 1970 Census of Population, $1 / 1000$ sample, 5 percent questionnaire.

The appropriateness of this data source was questioned by George Borjas in a number of articles throughout the 1980s (Borjas 1985, 1987, 1989). One major problem Borjas found was that Chiswick used data at a single point in time to project his earnings profiles. This causes a problem if the assumption that immigrants throughout the period have the same characteristics is shown to be false. Borjas' main argument is that immigrant cohort "quality" has changed over time, and that this implies that Chiswick cannot extrapolate his data to make such global statements about income.

The following section is a portion of a pilot study of immigrants to Sweden, which is intended to shed light on factors which affect income performance for various nationalities. To pursue this study, two very simple equations are used, which will help to illustrate the effects of nationality on relative income in Sweden. The first equation,

$$
\begin{aligned}
\text { In Income }= & \alpha+\beta_{1} \text { Age }+\beta_{2} \text { Sex }+\beta_{3} \text { Education }+\beta_{4} \text { CivilStatus }+ \\
& \beta_{5} \text { Country }_{1} \ldots \beta_{20} \text { Country }_{16}+\varepsilon
\end{aligned}
$$

is used to hold constant various demographic characteristics, while allowing for the observation of differences attributable to country of origin (among other things). This equation is admittedly too simple, and will be refined in later work, but can be useful in providing insight into rough differences in relative income. 
The second equation is quite similar to the first,

$$
\begin{aligned}
\text { In Income }= & \alpha+\beta_{1} \text { Age }+\beta_{2} \text { Sex }+\beta_{3} \text { CivilStatus }+\beta_{4} \text { Country }_{1} \ldots \beta_{19} \text { Country }_{16} \\
& +\varepsilon
\end{aligned}
$$

but removes education from the equation. This equation should give us the incomes of foreign- born workers relative to all Swedes of the same age, sex, and civil status. This is then used to give an understanding of the foreigners' relative educational level. If relative income according to equation 2 is higher than that from equation 1 , it is assumed that the immigrants have a higher average educational level than do natives of a similar age, sex, and civil status.

Since the Swedish economy has entered the post-industrial age, an emerging polarization has occurred into industrial and service employment with different income structures. Thus, this section looks at the industrial and service sectors separately. Omitted from the analysis are the agricultural, construction, and energy sectors, but these are largely dominated by native workers with only a very small percentage of employees being foreign-born. A problem with this division is that the structural changes which the economy has undergone over the past 30 years have resulted in a shift of certain occupations from the industrial sector to the service sector. While many companies in 1970 attempted to perform a number of activities "in house", resulting in these professions being classified "industrial", out-sourcing and consultants were often implemented in the 1980 s and 1990 s, resulting in a reclassification of some professions as "service" employment.

Below we have tables showing the relative incomes of foreign born workers logging $35+$ hours per week. ${ }^{5}$ The sources of the data are the 1970 and 1990 Censuses of the population. The purpose here is to show how income patterns have changed over time due to structural changes in the economy, as well as changes in cohort "quality." It is accepted that these tables do not adequately avoid Chiswick's trap, since they do not examine the same cohorts for both census periods. In later work there will be a more detailed study of income development with more census data included, but for illustrative purposes, only 1970 and 1990 are used here.

Table 4a shows incomes relative to natives for the 16 countries in the manufacturing industry for 1970 and 1990 , with and without education taken into account. The non-European countries (except the US) do not have values for 1970, since they did not begin to send immigrants on any large scale prior to the 1970 s. Table $4 \mathrm{~b}$ shows the same figures for the service sector. Both tables show average relative incomes controlling for sex, age, and civil status.

The tables below are striking in at least one respect: the positive relationship between relative income and years since migration seems to be lacking. Some countries do show this upwardly sloping income curve, but it is far from the rule, with many countries even registering increasing gaps between native and foreign-born incomes as time goes by. This seems to point to the fact that immigrants to Sweden do not appear to collect country-specific human capital after arriving to the extent that they can compete on equal footing with natives. It must be noted here, however, that the graphs obtained from the charts below do not represent a single cohort's income patterns over a longer period, but rather a collection of relative income levels for various cohorts at a given time. Thus, changes in cohort "quality" can definitely influence the shape of the curve.

${ }^{5}$ The period used to gather this information was October 4-10, 1970 and the entire month of October, 1990. 
T a b l e 4a. Relative income, manufacturing industry. 1970 and 1990 . Sweden $=100$

\begin{tabular}{|c|c|c|c|c|c|c|c|c|c|c|}
\hline \multirow[b]{2}{*}{$\begin{array}{l}\text { Years in } \\
\text { Sweden }\end{array}$} & \multicolumn{5}{|c|}{ Controlling for education } & \multicolumn{5}{|c|}{ Not controlling for education } \\
\hline & $\begin{array}{c}1-4 \\
\text { Years }\end{array}$ & $\begin{array}{c}5-9 \\
\text { Years }\end{array}$ & $\begin{array}{l}10-14 \\
\text { Years }\end{array}$ & $\begin{array}{l}15-19 \\
\text { Years }\end{array}$ & $\begin{array}{l}20+ \\
\text { Years }\end{array}$ & $\begin{array}{c}1-4 \\
\text { Years }\end{array}$ & $\begin{array}{l}5-9 \\
\text { Years }\end{array}$ & $\begin{array}{l}10-14 \\
\text { Years }\end{array}$ & $\begin{array}{l}15-19 \\
\text { Years }\end{array}$ & $\begin{array}{l}20+ \\
\text { Years }\end{array}$ \\
\hline Norway 70 & 97.8 & 103.3 & 112.1 & 102.9 & 100.1 & 100.5 & 107.6 & 120.2 & 107.5 & \\
\hline & 102.4 & & & & & & & & & \\
\hline nmark 70 & 96.2 & 98.0 & 99.2 & 98.7 & 99.5 & 94.8 & 96.7 & & 97.0 & \\
\hline 90 & 96.6 & 94.6 & 94.4 & 5.6 & & 93.6 & 93 & & & \\
\hline & 96.8 & 100.2 & 101.8 & 101.3 & & 94.0 & 97. & 99 & 99.9 & \\
\hline nland 90 & 101.5 & 101.8 & & & & & 101.3 & & & \\
\hline & 101.0 & 108.8 & 108.2 & 105.7 & & 102.4 & 110.1 & & & 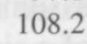 \\
\hline & 88.7 & & & & & & & & & \\
\hline- & 100.8 & 97.1 & 114 & 100.2 & & .2 & & & & 4 \\
\hline Unit & 82.9 & 84.8 & & & & & 10 & & & \\
\hline Gipe & 84.0 & 87.1 & & 99.4 & & & & 87.6 & & \\
\hline & & & & & & & & & & \\
\hline & 100.1 & 101.0 & 100 & 10 & & & & 10 & & \\
\hline & & & & & & 5 & 84.7 & 89.6 & & \\
\hline & 90.3 & 92.2 & 102 & 99.1 & & 3 & 92.2 & 118.8 & 115.7 & \\
\hline & 83.3 & 86.8 & 82.5 & 92.0 & & 77.5 & 81.7 & 77.4 & 86.7 & \\
\hline$Y_{u}$ & & & & & & & & & & \\
\hline & & & & & & & & & & \\
\hline & & & & 90 & & 78.4 & 90 & 92.3 & 9 & \\
\hline & & & & & & & & & 93.5 & \\
\hline & 81.4 & 102.0 & 96.5 & 101.2 & 103 & 91.4 & 112.0 & 98.5 & & 106 \\
\hline Czed & 75.7 & 89.6 & 88.9 & 92.1 & & 80.4 & 95.2 & 99.5 & 103.4 & 100 \\
\hline & 78.5 & 86.9 & 86.2 & 80.8 & & 76.4 & 85 & 85.5 & 82.7 & \\
\hline & 69. & & & 104.2 & & & & 78.6 & 101.0 & \\
\hline & & & & & & & & 90.7 & & \\
\hline & 73 & 90 & & 74.1 & 92 & 71.9 & 93.0 & 91.9 & 72.7 & \\
\hline Vietnam 90 & 91.2 & 92.6 & 100.3 & 58.8 & 92.2 & 82.5 & 86.2 & 94.2 & 54.9 & \\
\hline
\end{tabular}

Source: Statistics Sweden, 1970 and 1990 Censuses of the Population

Another point which is blatant in the tables is that immigrants recorded in the 1970 census had, in general, much higher relative incomes than did their countrymen in the 1990 census. For almost every country we see that relative income drops by at least 10 to 20 percentage points between the two censuses for individuals with comparable time in Sweden. There are only a few cases where immigrants in 1990 actually outperformed those arriving twenty years earlier. This is most likely a result of differing economic structures in 1970 and 1990. In 1970, Swedish industry was organized on a conventional, mass production basis. This implies that workers often had monotonous tasks requiring a great deal of repetition, but very little interpersonal contact. Immigrants did not have much difficulty fitting into this type of work. The decades following 1970 saw a shift towards increased use of workgroups and job rotation, among other organizational changes leading to increased need for language ability and other culture-specific knowledge, and more difficulty for immigrants to advance through the ranks. This process is noticeable in the lower labor force participation rates of migrants in more recent years.

Another point which is interesting to note, but not altogether unexpected, is the role that cultural distance plays in relative income. If one lists the countries in these tables according to cultural proximity to Sweden, it would have the following rough form: Scandinavia ${ }^{6}$, Northwestern Europe (including the United States), Southern Eu-

\footnotetext{
${ }^{6}$ In this paper, Scandinavia refers to Norway, Finland, and Denmark.
} 
T a b le 4b. Relative income, service sector. 1970 and 1990. Sweden $=100$.

\begin{tabular}{|c|c|c|c|c|c|c|c|c|c|c|}
\hline \multirow[b]{2}{*}{$\begin{array}{l}\text { Years in } \\
\text { Sweden }\end{array}$} & \multicolumn{5}{|c|}{ Controlling for education } & \multicolumn{5}{|c|}{ Not controlling for education } \\
\hline & $\begin{array}{c}1-4 \\
\text { Years }\end{array}$ & $\begin{array}{c}5-9 \\
\text { Years }\end{array}$ & $\begin{array}{l}10-14 \\
\text { Years }\end{array}$ & $\begin{array}{l}15-19 \\
\text { Years }\end{array}$ & $\begin{array}{c}20+ \\
\text { Years }\end{array}$ & $\begin{array}{c}1-4 \\
\text { Years }\end{array}$ & $\begin{array}{c}5-9 \\
\text { Years }\end{array}$ & $\begin{array}{l}10-14 \\
\text { Years }\end{array}$ & $\begin{array}{c}15-19 \\
\text { Years }\end{array}$ & $\begin{array}{l}20+ \\
\text { Years }\end{array}$ \\
\hline orway 70 & 104 & 101.6 & 108.5 & 66 & 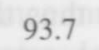 & 8.2 & 05.2 & 113.2 & & \\
\hline & & 95.0 & & & & & & & & \\
\hline k 70 & 103.7 & 100.7 & 94.5 & 93.0 & & 104.4 & 101.2 & 4.3 & & \\
\hline 90 & 105.1 & 105.3 & 103.0 & & 2.7 & 109.8 & 111.6 & 107.8 & & \\
\hline $\mathrm{n}$ & & & & & & & & & & \\
\hline L & & & & & & & & & & \\
\hline 70 & 104.0 & 105.3 & 10 & 100 & 107 & 106.2 & .1 & & & \\
\hline & & 804 & & & & & & & & \\
\hline 7 & & & & 92 & & & 119.3 & & & \\
\hline م & & & & & & & & & & \\
\hline & & & 117 & & & & & & & \\
\hline & 82.6 & 83. & & & & 75 & & & & \\
\hline ly & 820 & 86. & 86 & & & & 4 & & & \\
\hline & 82.4 & & 81.5 & 76. & 91 & 80.5 & 77.3 & 78.5 & 74 & \\
\hline & 89.0 & & 113.8 & & & & 5.5 & & 106.1 & \\
\hline & & & & & & & & & & \\
\hline & 87 & & & & & & & & & \\
\hline ag & 82.1 & 84 & 82. & 88 & & & 80.3 & 77.2 & & \\
\hline la & 70.7 & 90. & 86.8 & 99. & 86 & 79.2 & 106.4 & 97.4 & 106.1 & \\
\hline & 76.6 & & 88.2 & 88.7 & 92.7 & 80.3 & 87.4 & 91.9 & 93.2 & \\
\hline & & & 109.1 & 1010 & 104.9 & 113.1 & 100.3 & 117.2 & 106.6 & \\
\hline & & & & & & & & & & \\
\hline & & & & & & & & & & \\
\hline & 58 & & 74 & & & & & & & \\
\hline$x^{2}$ & 57.0 & 69 & 73 & 80. & 73 & & 71.4 & & 87.5 & \\
\hline & 76.9 & & & & 85 & 72.3 & 87.4 & 92.0 & 78.2 & \\
\hline coms & 65.6 & 78.1 & 83.7 & 99.4 & 91.7 & 61.6 & 71.3 & 78.0 & 94.0 & \\
\hline
\end{tabular}

Source: Statistics Sweden, 1970 and 1990 Censuses of the Population

rope, Eastern Europe, and last , the non-European countries. ${ }^{7}$ If one were to then compare relative incomes of these groups for each cohort, a picture of the role of cultural distance would develop. If we expect that this factor plays an important role, then those from Scandinavia would have the highest relative incomes, and those from non-European countries would have the lowest. This does not occur to any great extent in 1970, but it is clearly noticeable for the most recent immigrants in 1990. Here, those who had been in the country for only 1 to 4 years showed relative income patterns which compare to the cultural-distance hypothesis mentioned above. Scandinavians had the highest relative incomes, followed by the other groups in approximately the same order as their cultural rankings. This obvious difference disappears by the next cohort, however, when cultural distance seems to be offset by other factors. The most likely impact of this distance is in the ability to rapidly achieve linguistic proficiency as well as social skills necessary to compete favorably with natives. Another aspect of this distance which is not discussed here is the type of employment attained, where cultural distance may play a much more significant and long-lasting role.

Immigrants from the non-European countries seem to have the worst income performance of all foreign-born workers. At first glance, this would seem to be contrary

7 This ranking according to cultural distance can, of course, be questioned on many levels, and a more refined ranking system will be developed in later research. 
to accepted migration theory, which states that positive self-selection should increase as distance between origin and destination country increases. In Sweden's case, selfselection cannot be used as a primary argument regarding income performance, as almost all non-Europeans are refugees or tied movers. Explicit economic migration does not exist from these countries, and thus the immigrants received cannot be expected to behave in a rational economic manner when making the decision to migrate. This does not, of course, mean that there were no economic considerations behind the choice of which country to flee to, but this cannot be seen as the dominant factor.

Non-refugee immigrants from other countries cannot be considered economic migrants either, due to the changes in Swedish immigrant policy around 1970. They should have better chances for economic success than those from non-European countries for many reasons, however. Some came to Sweden as relatives of those already in the country, and thus came into an established group of countrymen who were able to assist them in entering either the mainstream Swedish labor market or an ethnic labor market. Others immigrated after having studied in Sweden or as a result of marriage/relationships with Swedish nationals. These individuals entered the country with some prior knowledge as to the workings of the society, and could also be assumed to do better than immigrants with no prior contact or acquaintances. Unfortunately, this hypothesis cannot be tested with the available data, as the censuses lack information on the type of visa used to gain entrance and residence in Sweden.

While nationality of an immigrant is definitely an important factor in income performance, it is our belief that there is another, more important factor that is often overlooked in the literature. This factor is the economic structure of the receiving country. As we all know, economic structure is not a static thing, and thus any examination of migration spread over 20 years or so must take into account the possibility of economic change. Chiswick's ground breaking article took into account only the human capital characteristics of migrants, plus geographic location. Borjas countered with the fact that immigrants are different in different cohorts. It is our firm belief that the shape of the economy when an immigrant enters a country affects not only his immediate economic success, but also his entire working life in the country.

Evidence of the impact of economic structure on income can be seen in a comparison of immigrant incomes in 1970 and 1990. The Sweden of 1970 was characterized by a truly industrial economy. Factories worked on the principles of standardization and conveyor belts. Industrial employment was task-oriented and required little communication between workers. This society had little trouble absorbing foreign workers, since welding and bolting required little language ability. By 1990, however, the Swedish economy had changed considerably. More intense international competition led to crisis and transformation during the 1970 s, and much industrial employment by 1990 was organized on a work-team principle. Much more emphasis was placed on the ability of workers to communicate with others in the workplace, and monotonous jobs were replaced by job rotation. These changes led to greater employee satisfaction, perhaps, but they also made it increasingly difficult for individuals with poor language abilities or little knowledge of the functioning of the Swedish society to obtain employment. These structural differences may also explain the declining relative incomes over time noticeable in some immigrant groups in 1990 . This could be because an immigrant entering the labor market in 1970 may have obtained employment in a sector which would soon become stagnant, and then keep that job throughout his career. This would then insure that the immigrant had a slower income development than would be the case had he found employment in an expansive sector, and thus have lower relative income, becoming increasingly more noticeable as time goes by. 


\section{Conclusions}

This paper has attempted to summarize briefly selected findings of two closely related pilot studies into immigrant assimilation and economic success. The idea here is that employment rates and income performance must be seen as two sides of the same coin. High incomes and low employment rates do not indicate successful adaptation to a new home country any more than do high employment rates and low relative wages. Unfortunately, this interdependence seems to be largely ignored in contemporary immigration literature.

Another factor which is equally ignored in the international literature is the effect which the national economic structure plays in the assimilation process. Barry Chiswick's famous work on immigrant income profiles examines only certain human capital and demographic characteristics among migrants to the United States. George Borjas criticizes Chiswick's approach on the valid grounds concerning the assumption of a constant "quality" among immigrants from the same country over time. This criticism is definitely on the right track, but falls far short of the mark. Time in the country must indeed play a major role in the assimilation process, but the role of time is likely to be affected most by changes in the economic structure. It is obvious that economies are dynamic beings, and even a relatively short span such as twenty years can bring about large changes in their functioning.

It is our belief that such a change is fundamental to understanding the assimilation of immigrants to Sweden over the past two decades. As has been mentioned in the earlier sections, the 1970 census takes a snapshot of a country enjoying respectable economic growth. The employment rates and income performance of immigrants at this time was largely a reflection of the strong economy. Shortly after entering the country, male immigrants showed rates which were comparable to, or higher than, native males, while foreign-born females quickly overtook native female employment rates. ${ }^{8}$ Relative incomes show a similar development, with the majority of the countries fal ling between 90 and 100 percent of Swedish incomes by the fifth year in the country, and with the majority of these countries reaching that point eve earlier.

The two factors just mentioned point to an economy which had little trouble in quickly absorbing relatively large numbers of migrants.

The 1990 census gives us another picture. As can be expected, most immigrant groups exhibit a sharp increase in labor force participation shortly after entering the country. The major difference between 1970 and 1990 is that very few immigrant groups actually reach or exceed native levels in 1990. The same is noticed for relative incomes, with almost all countries and cohorts registering lower relative incomes than their counterparts in 1970.

Although not expressly included in the paper, relative educational levels have changed over time. Current economists might suggest that declining educational levels are possible explanations for the declines in relative income and labor force participation. This would be a convenient, but incorrect explanation. The educational level of migrants in 1990 was higher than in 1970, but the same also applied to Swedes. Thus, relative educational levels for the foreign-born population shifted from being slightly above native figures to being only slightly below.

We therefore have a period in which human capital measured as educational level is increasing among immigrants at the same time that economic performance and as-

${ }^{8}$ The expansion of the public service sector, with its great demand for female labor, had begun by 1970 , but its course had yet to be completed. It is this sector which accounts for much of the dramatic rise in native female participation rates in 1990. 
similation is worsening. One possible explanation is that the composition of immigration has shifted towards an increased share of migrants from non-European countries, thereby increasing cultural distance (see Table 1). This explanation surely accounts for a great deal of the increasing assimilation problems, but this difficulty is also encountered by those countries which did well in the 1970 census.

The data above lead us to the conclusion that human capital theory does not in and of itself contain the key to an understanding of the assimilation process in postwar Sweden. While forming an excellent framework for beginning studies, it must be complemented to obtain a more complete understanding of the economic assimilation process of immigrants. It seems to us that one possible and promising complement is to be found in a structural-analytical approach - thereby taking the dynamic functioning of the economy into account. This path is currently being explored by the Research Group in Population Economics at Lund University

\section{References}

Bevelander, P. 1995. Labor Force Participation of Immigrants to Sweden. Unpublished Licentiate's dissertation. Lund University, Department of Economic History

Borjas, G. 1989. The self-employment experience of immigrants. Journal of Human Resources 21(4):485-506.

-. 1987. Self selection and the earnings of immigrants. American Economic Review 77(4):531-553.

-. 1985. Assimilation, changes in cohort quality, and the earnings of immigrants. Journal of Labor Economics 3(4):463-489

Chiswick, B. 1978. The effects of Americanization on the earnings of foreign-born men. Journal of Political Economy 86(3):897-921

Ekberg, J. 1983. Inkomsteffekter av invandring (Income effects of immigration). Doctoral Dissertation, Acta Wexionensia.Växjö.

-. 1991a. Försämrad sysselsättning för invandrarna under 1980-talet (Decreasing employment of immigrants during the 1980s). Ekonomisk Debatt 2. Lund: Nationalekonomiska föreningen

-. 1991b. Vad hände sedan? En studie av utrikes födda på arbetsmarknaden (What happened next? A study of foreign-born in the labor market). Acta wexionensia. Växjö

LaLonde, R.J. and R.H. Tobel. 1992. The assimilation of immigrants in the US market. In: Immigration and the Work Force: Economic Consequences for the United States and Source Areas, edited by G.J. Borjas and R.B. Freeman, pp. 67-92. Chicago, IL.: University of Chicago Press

Lundh, C and R. Ohlsson. 1994. Från arbetskraftimport till flyktinginvandring (From labor import to refugee immigration). Stockholm: SNS

Ohlsson, R. 1975. Invandrarna pä arbetsmarknaden (Immigrants in the labour market). Doctoral Dissertation. Lund: Ekonomisk-historiska föreningen

Ohlsson, R. 1978. Ekonomisk strukturförändring och invandring (Economic structural change and immigration). Lund: Ekonomisk-historiska föreningen.

Scott, K. 1995. Migrants in the Labor market: Employment Patterns and Income Development of Immigrants to Sweden 1970-1990. Unpublished Licentiate's dissertation. Lund University, Department of Economic History.

Schön, L. 1990. Elektricitetens betydelse för svensk industriell utveckling (The importance of electricity for industrial development in Sweden). FUD-raport. Vattenfall.

-. 1991. Development blocks and transformation pressure in macro-economic perspective - a model of long term cyclical change. Skandinaviska Enskilda Banken Quarterly Review 3-4.

-. 1993. 40-årskriser, 20-årskriser och dagens ekonomiska politik (Forty-year crisis, twenty-year crisis and today's economic policy). Ekonomisk Debatt 1. Lund: Nationalekonomiska föreningen.

-. 1994. Omvandling och obalans, mönster i svensk ekonomisk utveckling (Transformation and imbalance, patterns in Swedish economic development). Bilaga 3 till Långtidsutredningen. Stockholm.: Fritzcs.

Wadensjö, E. 1973. Immigration och samhällsekonomi (Immigration and social economy). Doctoral Dissertation. Lund: Studentlitteratur.

Wright, R.E. and P.S. Maxim. Immigration policy and immigrant quality: empirical evidence from Canada. Journal of Population Economics 6(4):337-52. 